\title{
Cost-Benefit Analysis of POME Biogas Power Plant: Case Study of PLTBg Suka Damai
}

\author{
Donny Yoesgiantoro \\ Faculty of Defence Management, Indonesia Defence University, Bogor, 16811 \\ energyprogram@gmail.com
}

Diterima: $14 / 04 / 2020$.

Direview: $21 / 04 / 2020$.

Diterbitkan: 31/08/2020

Hak Cipta $\odot 2020$ oleh Penulis (dkk) dan Jurnal Sosial Humaniora (JSH)

*This work is licensed under the Creative

Commons Attribution International License (CC BY 4.0).

http://creativecommons.org/licenses/by/4.0/ Open Access

\begin{abstract}
Subject Area: management
\section{Abstract}

Palm Oil Mill Effluent (POME) is a byproduct of processing fresh palm fruit bunches into crude palm oil (CPO) which has negative externalities in the form of gas containing methane, carbon dioxide and other greenhouse gases $(G H G)$ which is very dangerous for environmental sustainability. The use of pome as feedstocks for biogas power plants (PLTBg) changes the negative externalities of pome into positive externalities such as increased electrification in the area around the palm oil mill $(P K S)$ and is good for environmental sustainability. PLTBg Suka Damai with a capacity of $2.4 \mathrm{Mw}$ was planned to reach the Commercial Operating Date (COD) in 2019, the financial calculation has a cost-benefit ratio of 1.19, percentage of Internal Rate of Return (IRR) of $12.84 \%$, percentage of weighted cost of capital (WACC) $10 \%$ and a Net Present Value (NPV) of Rp 21,275,609,209.00. Comprehending all the results, the first scenario with SCOC is the most optimized scenario for it provides far greater benefits to the community, far greater than the financial revenue received by the PLTBg itself.
\end{abstract}

Keywords: Biogas; POME; waste to energy; carbon credit; energy.

\section{Introduction}

Tanah Bumbu Regency is one of the 13 (thirteen) Regencies in South Kalimantan Province which is located exactly at the southeastern tip of Kalimantan Island and has its capital in Batu Licin District. Tanah Bumbu Regency has 10 districts, namely Kusan Hilir, Loban River, Satui, Kusan Hulu, Batu Licin, Karang Bintang, Simpang Empat, Mantewe, Kuranji, and Angsana. The number of people living below the poverty line in Tanah Bumbu Regency in 2019 reached 17,340 people spread in 10 districts out of a total population of 350,452 people. The majority of Tanah Bumbu people works in agriculture, forestry, and fishery with a total of 43,937 people, followed by people working in the trade and restaurant area of 36,975 people in 2019 (Statistik, 2020).

The area of oil palm plantations in Tanah Bumbu Regency, both those owned by the public or private parties reaches an area of 86,994 hectares with a total production of 1,527,842 tons in 2019. Oil palm plantations located in Suka Damai Village, Mantewe District occupy an area of 16,780 hectares and produced 218,821 tons of palm oil in 2019. In 2017 Indonesia's electrification ratio only reached 95.35\% and increased to $99 \%$ in 2019. Most areas that have not been electrified are remote villages and border areas. The Government of the Republic of Indonesia through the Ministry of Energy and Mineral Resources 
and PT. PLN as the main utility company in Indonesia is trying to meet the $100 \%$ electrification target in 2020 especially through the use of new and renewable energy technologies.

In 2017, Indonesia produced 35,359,384 tons of oil palm with major producers in Sumatra, Kalimantan, and Sulawesi (Statistik, 2018; Perkebunan, 2016) which have a production capacity of 34,280 tons per hour (Rahayu, 2015). Pome has the potential to produce methane gas at $10 \%$ of national gas consumption, which is 54 million standard cubic feet (SCF). The use of pome as an energy source is a solution for adding value to the waste from PKS and minimizing greenhouse gas (GHG) emissions (Fiskal, 2014). Therefore, it can change the negative externalities from pome to positive externalities. The use of pome as an energy source also helps the government in increasing the electrification ratio and the energy mix in terms of renewable energy following the mandate of the National Energy General Plan (RUEN) (Indonesia, 2017). Therefore, the authors conducted a study on a cost-benefit analysis of the use of POME as feedstocks from biogas type power plants in Suka Damai Village which was planned to enter the Commercial Operating Date (COD) phase in 2019.

\section{Literature Review}

POME or palm oil mill effluent is a waste byproduct of processing fresh fruit bunches (FFB) into crude palm oil (CPO) by a palm oil mill (PKS). POME is one of the dominant elements from processing FFB into CPO, with a composition of $65 \%$ of the whole FFB itself. POME is one of the negative externalities of PKS because 50-75\% of the pome's biogas content is methane (CH4), 24-45\% is carbon dioxide (CO2) and the rest is $\mathrm{H} 2 \mathrm{O}, \mathrm{H} 2 \mathrm{~S}$, and other gases (Sugiyono, Juwita, Hastuti, \& Fitriana, 2019; Rahayu, 2015). A large amount of methane in the POME makes it potential to be main resource of biogas in a district with plenty of palm farms.

In general, the process of generating electricity with biogas is by converting biogas into thermal energy which is then used to heat the boiler so that it can produce high-pressure steam that can drive the generator (Dharmawan, Nuva, \& DA, 2016). Indonesia has huge potential in the usage of bioenergy as fuel to become biopower. Furthermore, bioenergy produced from biomass will produce energy in three (3) forms, namely thermal, e.g. the usage of firewood as feedstock for stoves and room heaters; biopower, by making biomass as a feedstock to heat the boiler and then be able to run the turbine; biofuels in solid, gas or liquid form (Dharmawan, Nuva, \& DA, 2016).

Social Cost of Carbon (SCOC) is the economic value associated with damage and environmental benefits derived from the quantification of carbon emissions tons/year (Howard, \& Sylvan, 2015). The SCOC assumption used is the average value of the value set by the US Environment Protection Agency of US \$ 40 (Ricke, Drouet, Caldeira, \& Tavoni, 2018) because Indonesia is at the same level as America (see figure 1). Reducing Emissions from Deforestation and Forest Degradation (REDD) is an effort to reduce emissions from deforestation and forest degradation; conservation efforts, sustainable management of forests and; efforts to increase forest carbon stocks in developing countries through policy approaches and also positive incentives (Angelsen, Brown, \& Loisel, 2009). 
Furthermore, REDD is the latest effort to mitigate climate change which simultaneously influences socio-economic and ecological levels at the local, subnational, national, regional and global levels (Agrawal, Nepstad, \& Chhatre, 2011). The value of carbon credit credits under the REDD scheme is US \$ 5 per tonne of carbon/year (Sudaryanti, Fauzi, Dharmawan, \& Putri, 2017).

Figure 1 Distribution of the amount of social cost of carbon
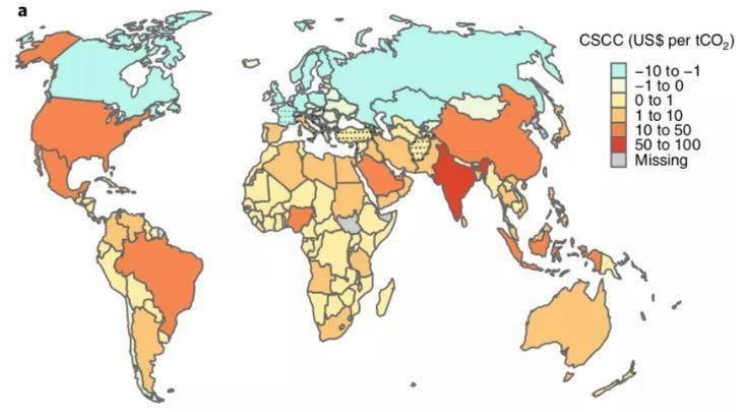

(Ricke et al, 2018)

Based on applicable regulations, the sale of electricity, especially those generated from a biogas power plant or PLTBg, follows the BOOT (build, own, operate and transfer) cooperation concept. The construction of electricity distribution lines to the PLN network is carried out by an independent power producer (IPP) company with a business to business (B to B) cooperation mechanism. Then if the cost of electricity generation (BPP) in the area where the power plant is built is higher than the national BPP tariff, the appropriate price is a maximum of $85 \%$ of the national BPP tariff (ESDM, 2017a). Moreover, IPP is also bound to guarantee the security of the supply of feedstock for PLTBg since the beginning of the validity of the Electricity Purchase Agreement (PPA) until the end of the agreement period with PT. PLN (Persero).

PPA regulates IPP rights and obligations towards PT. PLN (Persero)(ESDM, 2017b), such as IPP has the right to receive payment according to the BPP tariff agreed in the PPA; IPP has the right to get an incentive for accelerating the development of power plant to accomplish the commercial operation date (COD) if the acceleration of development at the request of PT. PLN (Persero); IPP also has the right to get deemed dispatch if PT. PLN (Persero) experienced a disruption other than force majeure.

IPP must implement BOOT until the PPA expires; IPP must provide a performance guarantee on the operation and performance of the plant; IPP is required to pay a penalty fee if it fails to meet the performance guarantee; IPPs are required to submit monthly projected availability factors (AF); IPP must distribute and sell electricity to PT. PLN (Persero) under projected AF; IPP must take care of all necessary permits; IPP must fulfill Domestic Component Level (TKDN); IPP must maintain the continuity of electricity supply during the period of the PPA; IPP must also pay all penalties following applicable regulations. 


\section{Methodology}

\section{Cost-benefits Analysis}

Economic cost-benefit analysis is a method developed specifically as a medium to evaluate a project using the factor of benefits and costs obtained or projected to be obtained from the project or policy. Furthermore, all potential benefits and costs are identified, then quantified into monetary units, and each outcome is compared to ease the evaluation of project or policy feasibility from society's standpoint (Nas, 2016).

In the economic cost-benefit analysis there are four (4) main keys, namely (a) the costs and benefits of the policy or project are identified and assessed using a community perspective; (b) costs and benefits are quantified in monetary units, in this case, the applicable currency; (c) the projected cost and benefit flow are reduced by the relevant discount percentage; and (d) the determination of project or policy eligibility is based on the basic principles of maximizing the benefits received by the community.

In this research, the author chose three scenarios in the calculation of costs and benefits. The first scenario is the benefit variable adds the social cost of carbon (SCOC) variable as one of the benefits received by the society. In the second scenario, the SCOC benefit variable is replaced by the Reducing Emissions from Deforestation and Forest Degradation (REDD) factor.

In the third scenario, the calculation does not include additional benefit variables such as REDD or SCOC, which only includes basic benefit variables such as electrification and diesel savings in Suka Damai Village. The formula for calculating the amount of diesel savings benefits uses the formula below (Yoesgiantoro, 2019)

$$
\begin{aligned}
& \mathrm{B}=(((\mathrm{k} * \mathrm{P} * \mathrm{t}) * \mathrm{p}) * \mathrm{~h}) * 365(1) \mathrm{B}=\text { diesel savings benefit (rupiah) } \\
& \mathrm{k}=\text { fuel specific consumption of diesel generators (liters } / \mathrm{kWh}) \\
& \mathrm{P}=\text { diesel generator power }(\mathrm{kVA}) \\
& \mathrm{t}=\text { duration of generator operation in one day (hour) } \mathrm{p}=\text { price of diesel fuel (rupiah) } \\
& \mathrm{h}=\text { number of families }
\end{aligned}
$$

The value of $\mathrm{k} * \mathrm{P} * \mathrm{t}$ can be changed to $\mathrm{f}$ or the amount of fuel used by diesel generators in one day of operation in liters if the amount of fuel consumption per day is known.

\section{Sensitivity Analysis with Switching Value Table}

The testing of the variables sensitivity that affect changes in NPV is done by using switching value analysis. Switching value analysis is a method of testing each value of the existing variable against the NPV. Testing is done by changing the value of the variable itself so that the NPV value becomes 0 or can be called reaching the break-even point. the testing also has to use the same percentage discount rate (ADB, 2010).

Changes to the variable are calculated by comparing with the initial value so that a percentage of change is obtained which is then called the switching value. The switching value is very beneficial to find the variables that influence the changes in the NPV. Referring to the value of switching value, stakeholders can optimally issue policies and actions that are able to minimize the effect of these variables. 


\section{Result and Discussions}

\section{Cost-benefits Variables}

\section{1). Benefits Variables}

There are five (5) variables that affect the value of benefits (See table 1), i.e electricity produced; BPP rates; SCOC value; the value of REDD; and the exchange rate used. In the variable power generated per year, assuming a full year of operation with a percentage value of a capacity factor of $92 \%$, the amount of power that can be generated by Suka Damai PLTBg is 19,422,000 kWh/year with an installed capacity of $2.4 \mathrm{Mw}$. Under the PPA acknowledged by both companies, the BPP rate used is $1,365 \mathrm{rupiah} / \mathrm{kWh}$. Moreover, for the SCOC and REDD variables, sequentially US \$ 40.00 per tonne carbon/year (Howard, \& Sylvan, 2015) and US\$ 5.00 per tonne carbon/year (Sudaryanti, Fauzi, Dharmawan, \& Putri, 2017). In the last variable, the exchange rate used is $\mathrm{Rp} 14,500.00$.

Table 1 Benefit Variables

\begin{tabular}{|l|r|c|}
\hline \multicolumn{3}{|c|}{ Benefit Variables } \\
\hline Power generated p.a. & 19.422 .000 & Kwh/yr \\
\hline BPP tariff & 1.365 & Rupiah \\
\hline Social Cost of Carbon (SCOC) & 40,00 & US Dollar \\
\hline $\begin{array}{l}\text { Reducing Emissions from Deforestation and } \\
\text { Forest Degradation (REDD) }\end{array}$ & 5,00 & US Dollar \\
\hline Exchange rates & 14.500 & Rupiah/USD \\
\hline
\end{tabular}

\section{2). Fixed Cost Variables}

In the table of fixed cost variables (see table 2), there are four (4) variables that are used as the basis for estimating fixed costs, i.e. capital expenditure (CapEx); O / M digester tool; feedstocks; and land lease. CapEx variable has a value of Rp 109,114,132,016.00 which originates from investment and development costs. Investment costs comprise digester construction Capex; power unit construction Capex; and grid connection cost with a total amount of Rp 103,402,188,204.00.

Development costs include contingency fees, office equipment, license and permit, tax, import duty with a total cost of Rp 5,711,943,813.00. The next variable is the acquisition cost of O/M digester tool having a value of Rp. 169,213,550.00 which expedites in the first year of COD. For a total cost of Rp. $795,331,497.00$, feedstocks are charged every year after the COD period. Lastly, the land lease variable is paid yearly at a cost of US $\$ 11,000.00$.

Table 2 Fixed Cost

\begin{tabular}{|l|r|l|}
\hline \multicolumn{3}{|c|}{ Fixed Costs } \\
\hline Capital Expenditure & 109.114 .132 .016 & Rupiah \\
\hline O/M Digester Tool & 169.213 .550 & Rupiah \\
\hline Feedstocks & 795.331 .497 & Rupiah \\
\hline Landlease & $11.000,00$ & US dollar \\
\hline
\end{tabular}




\section{3). Var. Cost Variables}

The variable cost table (see table 3) consists of eight (8) variables, namely $\mathrm{O} / \mathrm{M}$ digester, inflation rate for $\mathrm{O} / \mathrm{M}$ digester, gas engine availability, the number of gas engine; variable fee per engine per hour, offshore cost escalation, inflation rate, and corporate overhead. The variable $\mathrm{O} / \mathrm{M}$ digester has a value of Rp 1,095,050,000,00 and the percentage value of the inflation rate for O/M digester is $2 \%$, both of these variables are used to obtain the value of the $\mathrm{O} / \mathrm{M}$ digester in a cost-benefit analysis.

To determine the value of $\mathrm{O} / \mathrm{M}$ engine gas variable fee, variable gas engine availability was employed with a size of 9,312 hours; the number of the gas engine is 2 units; variable fee per engine per hour of IDR 181,500.00; and offshore cost escalation with a percentage of 4\%. Belatedly, to account for corporate overhead costs, the last two (2) variables are leveraged, particularly the inflation rate with a percentage of $2 \%$ and corporate overhead costs of $\mathrm{Rp} 576,016,350.00$.

Table 3 Variable Cost

\begin{tabular}{|l|r|l|}
\hline \multicolumn{3}{|c|}{ Variable Costs } \\
\hline O/M Digester & 1.095 .050 .000 & Rupiah \\
\hline Inflation rate for O/M digester & $2 \%$ & \\
\hline Gas Engine Availability & 9.312 & Hours \\
\hline Number of Gas Engine & 2 & unit \\
\hline Variable Fee per Engine per Hour & 181.500 & Rupiah \\
\hline Offshore Cost Escalation & $4 \%$ & \\
\hline Inflation Rate & $2 \%$ & \\
\hline Corporate Overhead & 576.016 .350 & Rupiah \\
\hline
\end{tabular}

\section{Cost-benefits Analysis}

\section{1). First Scenario}

The scenario I with the additional benefit value of the SCOC (see table 4) variable exhibits a brief break-even point, within four (4) years with a WACC percentage of $10 \%$. This is because the extent of benefits received annually from the SCOC variable is immense, around Rp. 35,667,216,000.00 which far greater than the benefits of power sales which are in the amount of Rp. 26,511,030,000.00. Based on the data displayed by the graph (see figure 2), the scenario I indicates a fairly stable benefit value of Rp. $60,000,000,000.00$ but with a slight descend occurred in the eleventh year (11) and continued into the twentieth year (20).

Table 4 First Scenario

\begin{tabular}{|l|r|l|}
\hline \multicolumn{3}{|c|}{ Scenario I with SCOC } \\
\hline Capex & 109.114 .132 .016 & Rupiah \\
\hline Benefit of power sales & 26.511 .030 .000 & Rupiah/year \\
\hline Benefit electrification & 4.526 .046 .720 & Rupiah/year \\
\hline Benefit SCOC & 35.667 .216 .000 & Rupiah/year \\
\hline Present Value of Ct & 109.114 .132 .016 & Rupiah \\
\hline
\end{tabular}




\begin{tabular}{|l|r|l|}
\hline Present Value of Bt & 503.500 .132 .609 & Rupiah \\
\hline WACC & 10 & $\%$ \\
\hline Payback & 4 & Year \\
\hline NPV & 394.386 .000 .593 & Rupiah \\
\hline IRR & 55 & $\%$ \\
\hline B/C ratio & 4,614 & \\
\hline
\end{tabular}

Moreover, by utilizing the results of the known net benefits, a mathematical equation (Pricillia, 2014) can be used to discover the IRR.

$$
\begin{aligned}
& I R R=I_{1}+\frac{N P V_{1}}{N P V_{1}-N P V_{2}}\left(I_{1}-I_{2}\right) \\
& I R R \quad=\text { Internal Rate of Return } \\
& N P V_{1}=\mathrm{NPV} \text { with a positive value } \\
& N P V_{2}=\mathrm{NPV} \text { with a negative value } \\
& I_{1} \quad=\text { The discount rate that causes a positive NPV } \\
& I_{2} \quad=\text { The discount rate that causes a negative NPV }
\end{aligned}
$$

Figure 2 Comparation between net benefits, discounted net benefits and net present value of scenario I

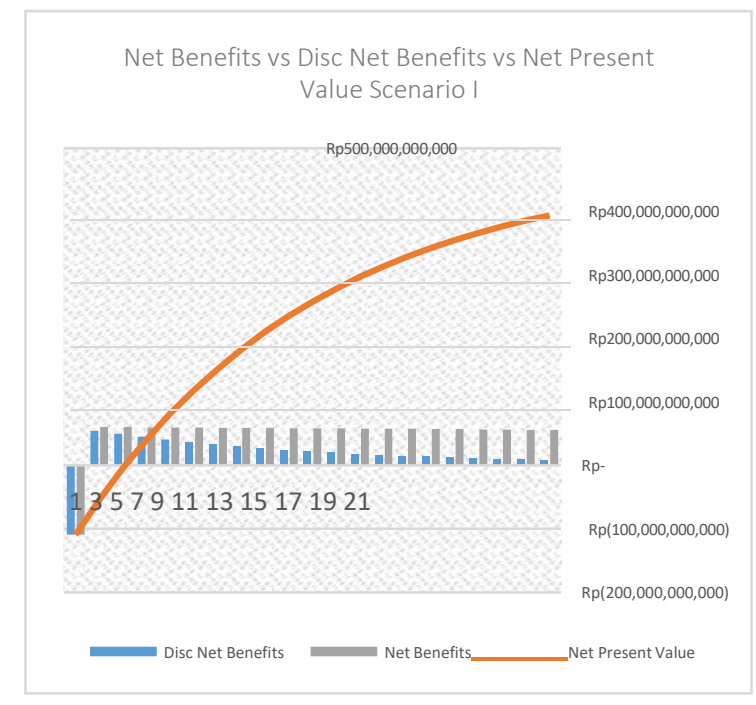

Overall, the amount of the benefits obtained by the addition of the SCOC variable has a present value of the cost of $\operatorname{Rp~109,114,132,016~and~present~value~of~the~benefit~of~} R p 503,500,132,609$. The results of calculating the present value of the benefits minus the present value of the costs produce a Net Present Value (NPV) of Rp. 394,386,000,593. Furthermore, by leveraging the value of net benefits annually, the result shows that the percentage of the Internal Rate of Returns (IRR) is at 55\%. It authenticates that scenario I contributes many benefits for the community. Finally, the value of the cost-benefit ratio is achieved by using the formula below: 
$\mathrm{B} / \mathrm{C}$ ratio $=$ present value of benefits / present value of costs

(3) Then we distribute the value of the benefits $(\mathrm{Bt})$ and costs $(\mathrm{Ct})$ into the formula above:

$\mathrm{B} / \mathrm{C}$ ratio $=503,500,132.609 / 109,114,132,016$

$\mathrm{B} / \mathrm{C}$ ratio $=4,614$

The result reveals that this scenario is attainable to be carried out and also provides great benefits to the community.

\section{2). Second Scenario}

In the second scenario (see table 5), the REDD + variable replaces SCOC in the first scenario. Using the same method and formula, the results of the analysis in the second scenario show an NPV value of IDR 129,407,787,628.00; IRR 26\%; and a cost-benefit ratio of 2,186. Seeing the value of the cost-benefit ratio and IRR in scenario II, the PLTBg project with the addition of a REDD + benefit variable is also feasible considering the great benefits for the community even though the amount is not as large as what was generated by scenario I.

Table 5 Scenario II with REDD+

\begin{tabular}{|l|r|l|}
\hline \multicolumn{3}{|c|}{ Scenario II with REDD+ } \\
\hline Capex & 109.114 .132 .016 & Rupiah \\
\hline Benefit of power sales & 26.511 .030 .000 & Rupiah/year \\
\hline Benefit electrification & 4.526 .046 .720 & Rupiah/year \\
\hline Benefit REDD+ & 4.458 .402 .000 & Rupiah/year \\
\hline Present Value of Ct & 109.114 .132 .016 & Rupiah \\
\hline Present Value of Bt & 238.521 .919 .644 & Rupiah \\
\hline WACC & 10 & $\%$ \\
\hline Payback & 6 & Year \\
\hline NPV & 129.407 .787 .628 & Rupiah \\
\hline IRR & 26 & $\%$ \\
\hline B/C ratio & 2,186 & \\
\hline
\end{tabular}

Figure 3 Comparation between net benefits, discounted net benefits and net present value scenario II

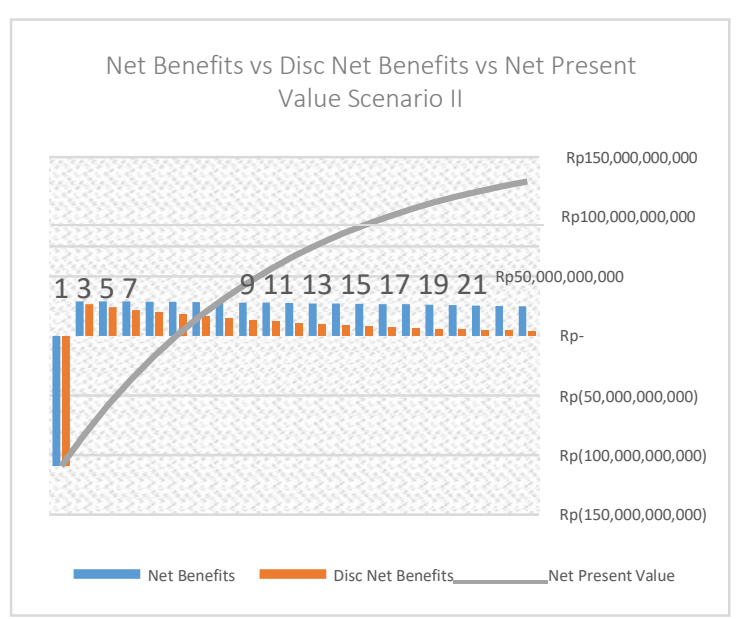


Net benefits obtained per year are at Rp. 30,000,000,000.00 and are declining slowly in the thirteenth year (13) and continue until the twentieth (20). With a WACC percentage of $10 \%$, the net benefits

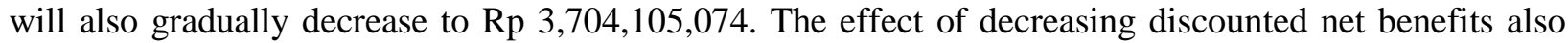
results in a slowdown of the NPV line starting in year 10 (see figure 3).

\section{3). Third Scenario}

Scenario III (See table 6) only includes basic benefit variables such as power sales and electrification. Without additional benefit variables such as SCOC or REDD+, the present value of benefits is $\mathrm{Rp} 199,845,016,487.00$, IRR $22 \%$, cost benefit ratio 1,832. These results indicate that the scenario is also quite feasible (see figure 4), but with the lowest NPV results compared to scenarios one and two. The third scenario can be seen as the current BAU scenario, so this finding reinforces the conclusion of the importance of carbon credit for environmentally friendly businesses.

Table 6 Scenario III without SCOC and REDD+

\begin{tabular}{|l|r|l|}
\hline \multicolumn{3}{|c|}{ Scenario III without SCOC and REDD+ } \\
\hline Capex & 109.114 .132 .016 & Rupiah \\
\hline Benefit of power sales & 26.511 .030 .000 & Rupiah/year \\
\hline Benefit of electrification & 4.526 .046 .720 & Rupiah/year \\
\hline WACC & 10 & $\%$ \\
\hline Payback & 8 & Year \\
\hline NPV & 90.730 .884 .471 & Rupiah \\
\hline IRR & 22 & $\%$ \\
\hline B/C ratio & 1,832 & \\
\hline
\end{tabular}

Figure 4 Comparation between net benefits, discounted net benefits and net present value

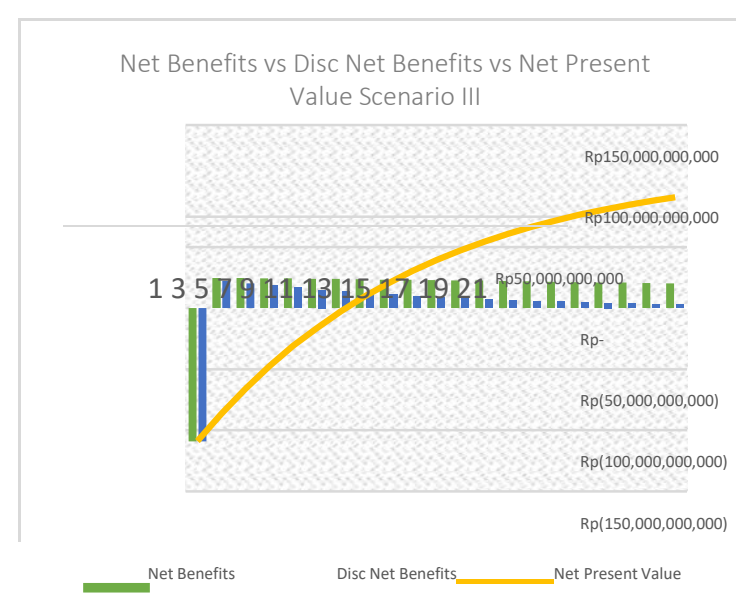

\section{Sensitivity Analysis}

Based on the results of data analysis on the calculation of benefit costs above, it can be concluded that the first scenario is the scenario with the best value. Then it can be continued with the calculation of sensitivity analysis in the first scenario. In this scenario, there are 10 main variables with various sub- 
variables that affect changes in NPV (see table 7). The first variable, the benefit of power sales has two sub-variables such as annual power generation and the BPP tariff by the PPA. The power generation has a switching value of $-174.74 \%$ while the BPP tariff is $-174.73 \%$. Second, the benefit of the electrification variable only reached the breakeven point at -Rp 41,798,384,925 with a percentage of switching value of $1,023.51 \%$.

Table 7 Switching Value of Scenario I

\begin{tabular}{|c|c|c|c|}
\hline \multicolumn{4}{|c|}{ Switching Value of Scenario I } \\
\hline $\begin{array}{c}\text { Scenario 1 } \\
\text { NPV = } \\
\text { Rp394.386.000.593 }\end{array}$ & Original Value & $\begin{array}{c}\text { NPV }=0 \\
\text { Break-even Point }\end{array}$ & $\begin{array}{c}\text { \% Change } \\
\text { Switching Value }\end{array}$ \\
\hline \multicolumn{4}{|l|}{ Power Sales Benefits } \\
\hline Power Generation & 19.422 .000 & -14.515 .313 & $-174,74 \%$ \\
\hline BPP Tariff & 1.365 & -1.020 & $-174,73 \%$ \\
\hline Electrification Benefits & 4.526 .046 .720 & -41.798 .384 .925 & $-1.023,51 \%$ \\
\hline SCOC tariff & 40 & $-11,95$ & $-129,88 \%$ \\
\hline Capex & 109.114.132.016 & 503.500 .132 .609 & $361,44 \%$ \\
\hline $\mathrm{O} / \mathrm{M}$ digester tool & 169.213 .550 & 433.993.814.202 & $256.376,99 \%$ \\
\hline Feedstocks & 793.331 .497 & 47.119.763.142 & $5.824,54 \%$ \\
\hline \multicolumn{4}{|l|}{ Lendlease } \\
\hline Lendlease & 11.000 & 3.205 .788 & $29.043,53 \%$ \\
\hline Exchange Rate & 14.500 & -4.417 & $-130,46 \%$ \\
\hline \multicolumn{4}{|l|}{$\mathrm{O} / \mathrm{M}$ digester } \\
\hline $\mathrm{O} / \mathrm{M}$ digester & 1.095 .050 .000 & 40.796 .380 .773 & $3.625,53 \%$ \\
\hline Inflation rate for $\mathrm{O} / \mathrm{M}$ digester & $2 \%$ & $36,26 \%$ & $1.713 \%$ \\
\hline \multicolumn{4}{|l|}{$\mathrm{O} / \mathrm{M}$ gas engine variable fee } \\
\hline Gas engine availability & 9.312 & 102.268 & $998,24 \%$ \\
\hline Variable fee & 181.500 & 1.993 .303 & $998,24 \%$ \\
\hline Offshore cost escalation & $4 \%$ & $27,24 \%$ & $581 \%$ \\
\hline \multicolumn{4}{|l|}{ Corporate overhead } \\
\hline Corporate overhead & 576.016 .330 & 40.227 .347 .123 & $6.883,72 \%$ \\
\hline Inflation rate & $2 \%$ & $41,6 \%$ & $1.980 \%$ \\
\hline
\end{tabular}

Third, the SCOC variable with an initial value of USD 40 per tonne of carbon per year reached the break-even point of the NPV if the tariff decreased to USD -11.95 resulting in this variable having a switching value of $-129.88 \%$. Furthermore, if the capital expenditure increases to Rp. 503,500,132,609, then the NPV value will be zero (0), this variable has a value of a switching value of $361.44 \%$. Fifth, the $\mathrm{O} / \mathrm{M}$ variable digester tool with an initial value of $\mathrm{Rp} 169,213,550$ will make the NPV value zero (0) if it experiences an increase in value of up to $\mathrm{Rp} 433,993,814,202$, the switching value of this variable is $256,376.99 \%$. 
Sixth, feedstocks with an increase of up to 5,824.54\% at Rp 433,993,814,202 will make the NPV break-even. Land lease costs consist of initial rental costs with a total initial cost of USD 11,000.00 and if these costs increase to USD 3,205,788.00 then the NPV will break even with a switching value of $29,043.53 \%$. The sub-variable of the dollar exchange rate has an initial value of Rp 14,500 with a breakeven point value of $\mathrm{Rp}-4,417$ in which the percentage of switching value is at $-130.46 \%$.

$\mathrm{O} / \mathrm{M}$ variable digester has two sub-variables namely $\mathrm{O} / \mathrm{M}$ digester with an initial value of $\mathrm{Rp}$ $1,095,050,000$ and Inflation rate for $\mathrm{O} / \mathrm{M}$ digester at the point of $2 \%$. In the $\mathrm{O} / \mathrm{M}$ sub-variable, an increase of 3,625.53\% with a value of Rp 40,796,380,773 makes the NPV reach zero (0), whereas for the Inflation rate for $\mathrm{O} / \mathrm{M}$ digester, an increase of $36.26 \%$ will make the NPV value become even, which has a switching value of $1,713 \%$.

The next main variable is the $\mathrm{O} / \mathrm{M}$ gas engine variable fee consisting of gas engine availability, variable fee, and offshore cost escalation. In the gas engine availability, an increase of 102,268 hours will change the NPV value to zero (0), the switching value for this sub variable is $998.24 \%$. Then in the variable fee, an increase in the percentage of switching value up to $998.24 \%$ will make the NPV value even. Finally, in the offshore cost escalation, an increase of $581 \%$ to point $27.24 \%$ will result in a zero NPV (0).

The last main variable, corporate overhead, consists of corporate overhead and inflation rate. Consequently, corporate overhead and inflation rates have a base value of Rp 576,016,330 and 2\%. The increase of both of them to the value of Rp. 40,227,347,123 and 41.6\% affected the value of the NPV to zero $(0)$. The switching value of corporate overhead is $6,883.72 \%$ and the inflation rate is $1,980 \%$.

\section{Final Verdict}

Comprehending all the results, then scenario I with SCOC shows the highest NPV value with a value of Rp. 394,386,000,593, with the fastest payback time i.e. the third year (3). This is strengthened by the value of the IRR and the cost-benefit ratio of this scenario, which is 55\% and 4,614. This proves that by adding SCOC in the PLTBg Suka Damai project, it will provide far greater benefits to the community, far greater than the financial benefits received by the PLTBg itself.

In the financial calculation of PLTBg Suka Damai, the value of the Financial NPV shows a magnitude of $\operatorname{Rp} 21,275,609,209$ with an IRR of 12.84 and a cost-benefit ratio of 1.19. This also bolsters the fact that this project is beneficiary to the welfare of the community. Though in financial calculations it does not generate immense revenue, the multiplier effect generated by this project over a span of 20 years far exceeds it.

In testing the sensitivity of each variable in scenario I, the variable with the switching value closest to 0 is electricity sales, respectively annual electricity production and the UN tariff have switching values of $-174.74 \%$ and $-174.73 \%$. This shows that a decrease in both the amount of annual electricity production and the BPP rate would make PLTBg in this scenario inappropriate. Besides, SCOC is the third variable that is the most sensitive to changes in NPV value, a decrease in the value of tons of carbon per year exceeding the $129.88 \%$ level would make the project in this scenario unfeasible. 
But in practice, a negative number on the variables that change the NPV value is something that is not real so that variables that have a negative number can be removed from consideration. Therefore, it can be concluded that CapEx is the most sensitive variable affecting NPV values. If the CapEx value exceeds IDR 503,500,132,609, it will cause the NPV to be negative so the project is not feasible to proceed. Several factors can make the cost of capital expenditure exceeds what has been budgeted. Therefore, the PLTBg must be able to complete licensing and COD according to the target. If the COD period exceeds the target it can make the CapEx costs swell and also reduce the benefits that can be received.

\section{Conclusions and Recomendations}

\section{Conclusions}

1. The first scenario with carbon credit in the form of SCOC generates an NPV value of Rp $394,386,000,593$ with an IRR percentage of $55 \%$ and a cost-benefit ratio value of 4,614. In the second scenario using the cost of REDD+ carbon credits results in an NPV value of Rp $129,407,787,628$ with a value-benefit ratio of 2,186 and an IRR percentage of $26 \%$. Finally, in the third scenario only with variable benefits from electricity sales and electrification benefits, this scenario has an NPV value of Rp. 90,730,884,471 with a percentage of IRR of $22 \%$ and a costbenefit ratio of 1,832 .

2. Based on the results of a cost-benefit analysis and sensitivity test with a switching value table, it shows that the PLTBg project in the first scenario far outperforms the other scenarios. This is proven by the NPV value, IRR percentage and cost-benefit ratio that is greater than the NPV value, IRR and cost- benefit ratio in the second and third scenarios.

3. Looking at the sensitivity test results by looking at the percentage of switching value, CapEx is one of the variables that have high volatility. To minimize the increase in CapEx exceeding 361.44\%, it is necessary to pay special attention to the cost components contained in the CapEx, especially the cost of procuring digesters and generators which constitute $85 \%$ of the overall CapEx cost component.

4. PLTBg Suka Damai with a capacity of $2.4 \mathrm{MW}$ can produce electricity up to $19,422 \mathrm{MWh}$ /year with a plant factor of 92\%; parasitic and 5\% grid loss; and 3\% own use. Electricity sales price or BPP tariff according to the approved PPA is Rp 1,365 per $\mathrm{kWh}$. This PLTBg project has a WACC percentage of 10\% with a total CapEx cost of Rp 109,114,132,016 consisting of investment and development costs. The Suka Damai PLTBg project is planned to reach COD in 2019. Based on the results of financial calculations, the Suka Damai PLTBg project has an NPV value of Rp $21,275,609,209$ with an IRR percentage of $12.84 \%$ and a cost-benefit ratio of 1.19 with a payback period of seven (7) years. 


\section{Recommendations}

1. Further research can further examine the externalities as a result of the operation of the POMEpowered biogas power plant in a span of more than five (5) years so that it can enrich research on the effects of operating the POME PLTBg in the long term.

2. Further research is needed to see the level of sensitivity and the potential occurrence of each variable on NPV values using sensitivity testing methods such as Monte Carlo Simulation to be able to provide a sharper picture so that stakeholders can provide far more optimal policies.

3. Research on the feasibility of large scale POME power plant development needs to be carried out considering the large number of palm oil producers in Indonesia and Indonesia's position as the number one producer (1) CPO in the world (Harihastuti, 2015) with total annual production of 29 344,479 tons (Perkebunan, 2015) per 2014 and growing to become 35,359,384 tons as of 2017 (Perkebunan, 2016).

4. Seeing the percentage of switching value in CapEx, then independent power producer (IPP) can minimize the volatility of CapEx by keeping the construction period carried out on time or even earlier so that it can get incentives from PLN, then ensuring licensing and import of generator procurement can run smoothly. Delays during the COD period, in addition to eliminating the potential revenue from electricity sales, the IPP must also pay a COD late fee penalty (ESDM, 2017b).

5. The use of POME as fuel for biogas power plants shows that it can change the value of negative externalities from POME to positive externalities, both for the community and for environmental sustainability. It can also meet the electrification ratio of areas around oil palm plantations and can help reduce energy deficits in areas around coconut plantations palm oil. So, business entities, both private and state-owned, can develop POME-based PLTBg either independently or in collaboration with oil palm planters or local palm oil mill owners.

6. Comprehending the results shown in this study, the authors suggest two recommendations for public policy relating to the pricing policy and the reformation of PLN.

a. Pricing Strategy

Based on the current law, power generated from renewable energy such as biogas is purchased by PLN at $85 \%$ of the BPP tariff in force in the region. Conversely, if power plants are powered by fossil energy, the selling price of electricity is $100 \%$ of the BPP tariff.

Fossil-powered power plants generate a lot of pollution and negative externalities that harm either society and nature alike. So, the author recommends that the pricing policy of renewable energy such as biogas, receives better pricing rates considering the positive externalities occurring from the operation of renewable energy power plants.

The author recommends a better pricing policy so that renewable energy power plants have a higher selling price compared to fossil-fueled powered plants. The increased of the BPP tariff for renewable energy power plants can come from carbon credits or carbon trade with a special mechanism. The carbon trade mechanism must be regulated in such a way that Independent 
Power Producers who want to get additional incentives at the BPP rate can request a "carbon permit" issued by the government or the Ministry of Energy and Mineral Resources to be precise.

The increase in BPP rates is expected to encourage a reduction in greenhouse gas emissions in Indonesia following the previously set targets. The government standardizes the level of emission limits in one region and encourages Independent Power Producers to participate in developing renewable energy power plants. the source of funds for the increased BPP rates for renewable energy power plants can come from industries and plants that generate emissions that exceed a certain level. The amount of costs that must be paid by the industry can be divided into several levels based on how much emissions they produce.

This is done to help Indonesia's self-sufficiency in increasing the amount of power generation from renewable energy and reducing greenhouse gas emissions. The government can no longer expect from the support of foreign countries in terms of carbon credit incentives due to the continued heavy politicization. The amount of incentives that can be given by foreign countries depends on how immense their national interests are in Indonesia.

b. PLN Reformation

The author's second recommendation is the reformation of PLN. In the pre-reformation era, PLN as a state-owned company in the field of electric utilities made it the only player in the procurement and sale of power. The monopoly carried out by PLN arose naturally based on the laws in force at the time. Post reformation period, gradually PLN received early reform even though the scale was still minute.

Now the system is no longer fully monopolized by PLN, but it is turned into an oligopoly system. In this system, the generation of power starts to be generated by Independent Power Producers, but in the case of electricity sales, it is still under full control by PLN. So in my opinion, this system is still not perfect. It is necessary to make a regulation that gives freedom to the private sector to be able to participate in selling electricity, both self-produced or purchased from other Independent Power Producers or PLN, directly to consumers.

This will certainly create a good market condition for people's welfare. A free-market system that has multi-sellers and multi-buyers will certainly encourage innovation which is certainly beneficial to both society and government. Besides, the authors recommend the creation of a non- ministerial institution that specifically regulates companies that participate in selling electricity to minimize unfair competition and can form a mutualism system. Like the Upstream Oil and Gas Supervisory Agency (BPH Migas) in the oil and gas sector, a similar institution must be established in the electric utility sector. 


\section{References}

ADB (2010) Introductory Course on Economic Analysis of Investment Projects Session 3.3 Sensitivity and Risk Analysis. Asian Development Bank.

Agrawal, A., Nepstad, D., \& Chhatre, A. (2011). Reducing emissions from deforestation and forest degradation. Annual Review of Environment and Resources, 36, 373-396.

Angelsen, A., Brown, S., \& Loisel, C. (2009). Reducing emissions from deforestation and forest degradation (REDD): an options assessment report.

ESDM, K. (2017a) Peraturan Menteri Energi dan Sumber Daya Mineral Republik Indonesia Nomor 50 Tahun 2017 Tentang Pemanfaatan Sumber Energi Terbarukan Untuk Penyediaan Tenaga Listrik.

ESDM, K. (2017b) Peraturan Menteri Energi dan Sumber Daya Mineral Republik Indonesia Nomor 10 Tahun 2017 Tentang Pokok-Pokok Dalam Perjanjian Jual Beli Tenaga Listrik.

Fiskal, B. K. (2014) Analisis Biaya dan Manfaat Pembiayaan Investasi Limbah Menjadi Energi Melalui Kredit Program. Jakarta: Badan Kebijakan Fiskal.

Dharmawan, A. H., Nuva, R. A., \& DA, S. (2016). Isu Relevan Kebijakan Bioenergi Dalam Mendukung Ketahanan Dan Kemandirian Energi Di Indonesia: State of the Art.

Harihastuti, N. (2015). Potensi Airlimbah Industri Kelapa Sawit (CPO) sebagai Sumber Bioenergi Terbarukan. In Seminar Nasional Pangan Lokal, Bisnis, Dan Ekoindustri.

Howard, P. H., \& Sylvan, D. (2015). The Economic Climate: Establishing Expert Consensus on the Economics of Climate Change. Institute for Policy Integrity, 438-441.

Indonesia, R. (2017). Peraturan Presiden No. 22 Tahun 2017 tentang Rencana Umum Energi Nasional. Lembaran Negara RI Tahun, (43).

Nas, T. F. (2016). Cost-benefit analysis: Theory and application. Lexington Books.

Perkebunan, D. J. (2015) Pertumbuhan areal kelapa sawit. Jakarta: Direktorat Jendral Perkebunan Kementerian Pertanian.

Perkebunan, D. J. (2016). Statistik perkebunan indonesia 2015-2017. Jakarta: Direktorat Jendral Perkebunan Kementerian Pertanian.

Pricillia, S. A. (2014) Analisis ekonomi pemanfaatan fiber dan cangkang kelapa sawit menjadi energi listrik (studi kasus: PT. Bahana Karya Semesta, Kab. Sarolangun, Jambi). Departemen Ekonomi Sumberdaya dan Lingkungan, Fakultas Ekonomi dan Manajemen, Institut Pertanian Bogor.

Rahayu, A. S. (2015). Buku Panduan Konversi POME menjadi Biogas Pengembangan Proyek di Indonesia.

Ricke, K., Drouet, L., Caldeira, K., \& Tavoni, M. (2018). Country-level social cost of carbon. Nature Climate Change, 8(10), 895-900.

Statistik, B. P. (2018). Statistik Indonesia 2018. Jakarta (ID): Badan Pusat Statistik.

Statistik, B. P. (2020). Tanah Bumbu Regency in Figures 2020. Tanah Bumbu (ID): Badan Pusat Statistik. 
Sudaryanti, D. A., Fauzi, A., Dharmawan, A. H., \& Putri, E. I. K. (2017). Bioenergy and Social Economic Transformation in Rural Area (Case Studies: Talau Village and Tanjung Beringin Village, Pelalawan Regency, Riau Province). Sodality: Jurnal Sosiologi Pedesaan, 5(3).

Sugiyono, A., Juwita, A. R., Hastuti, Z. D., \& Fitriana, I. (2019). Kajian Tekno Ekonomi Upgrading Biogas Berbasis POME Dengan Teknologi Water Scrubber.

Yoesgiantoro, D. (2019) Battery Energy Storage System Sebagai Solusi Optimal Elektrifikasi di Wilayah Tertinggal, Terdepan dan Terluar: Analisis Biaya-manfaat 